Article

\title{
Leo Tolstoy's Anticlericalism in Its Context and Beyond: A Case against Churches and Clerics, Religious and Secular
}

\author{
Alexandre Christoyannopoulos \\ Department of Politics, History and International Relations, Loughborough University, \\ Loughborough LE11 3TU, UK; a.christoyannopoulos@lboro.ac.uk; Tel.: +44-1509-222-983 \\ Academic Editor: Todd Green \\ Received: 27 November 2015; Accepted: 12 May 2016; Published: 20 May 2016
}

\begin{abstract}
In the last thirty years of his life, Leo Tolstoy wrote numerous books, essays and pamphlets expounding his newly-articulated views on violence, the state, the church, and on how to improve the human condition. Since then, these "Christian anarchist" views have often been dismissed as utopian or naive, and, despite inspiring many activists and intellectuals, often forgotten or ignored. Some of those views and arguments, however, arguably remain apposite today-and can in some cases be applied to broader phenomena than those he identified. This article focuses on one of the aspects of his Christian anarchist thought: his anticlericalism. The first Section recounts the evolution of Tolstoy's views on religion and the church, and briefly describes Tolstoy's peculiar metaphysics. The second outlines his main charges against the church, discusses some common objections to it, and considers the continuing relevance of his anticlericalism. The third seeks to secularise his anticlerical arguments by applying them beyond the church, against secular preachers and institutions, and does so by reflecting on the quality of debate in the contemporary public sphere, on the hypocritical distance between the morality preached by secular "clerics" and their practice, and on the steady process of ossification and betrayal which befalls secular political ideals. The article thus contributes to the literature firstly by summarising, discussing and reflecting upon the anticlericalism of a famous writer who also espoused controversial religious and political views; secondly by succinctly outlining his idiosyncratic metaphysics, including his peculiar reinterpretation of traditional Christian referents; and thirdly by applying the arguments that informed his criticisms of the church to a broader variety of religious and secular secular institutions.
\end{abstract}

Keywords: anticlericalism; Christian anarchism; political theology; religion and politics; secular institutions; Tolstoy

\section{Introduction}

Leo Tolstoy (1828-1910) produced two of the world's most acclaimed works of fiction in War and Peace and Anna Karenina, but, at the time of his death, was at least as famous for the radical religious and political views which he propounded in the last thirty years of his life. These "Christian anarchist" reflections are sometimes remembered today within pacifist and anarchist circles, but are barely known by the general public outside of that milieu. This limited knowledge about Tolstoy's Christian anarchist writings might be as much the result of their eccentric radicalism as of their drowning in the downpour of mass violence that submerged the world in the years that followed his death. In scholarly circles, Tolstoy's religious writings have received significant attention [1-12] , as have the movements and communities that some of his followers set up [13-18], yet in political science, a few notable exceptions aside [19-24], Tolstoy's thought tends to receive little more than passing mention. Nowadays, therefore, Tolstoy is often primarily remembered for his fiction, and, outside some academic disciplines, his later political and religious writings are often ignored or dismissed. 
This article focuses on one of the key themes in Tolstoy's Christian anarchist thought: his anticlericalism. It aims to outline Tolstoy's anticlericalism and discuss its contemporary relevance, but also to apply core elements of what was a critique of the church to non-church, secular phenomena. It is structured in three main sections, each divided in further subsections. The first section (i.e., Section 2) recounts the evolution of Tolstoy's views on Christianity by considering his opinion on religion in his earlier years, his late "conversion" to (his interpretation of) Christianity, his idiosyncratic metaphysics, and his gradual estrangement from the institutional church. The second main section (i.e., Section 3) focuses on his anticlericalism first by outlining his main charges against the church, then by discussing some common objections to it, and then by considering the continuing pertinence of his critique of religious clericalism. The final section (i.e., Section 4) seeks to reflect on the broader applicability of the arguments informing his anticlericalism to secular institutions by discussing three themes in particular: the importance of rational scrutiny in public debate, the assessment of preachers and institutions by their actions, and the "clericalising" drift arguably afflicting all institutions, religious or secular.

Tolstoy's claims about the church are not exceptional in that many others have expressed similar criticisms. However, one of the contributions this article makes to the literature is to summarise, discuss and reflect upon the anticlericalism of this specific and notorious writer and critic-one whose views had significant impact in his context. In the process, this article also offers an original analysis of Tolstoy's idiosyncratic metaphysics and his peculiar understanding of traditional Christian concepts. Furthermore, the article also presents an original application of the arguments that drive Tolstoy's criticisms of the church to a broader variety of non-church institutions, thus extracting some of the reasoning which led Tolstoy to criticise the church in his specific context and grafting it onto a broader set of phenomena.

\section{Tolstoy's Journey to Anticlericalism}

It might be helpful to first recall some of the relevant aspects of Tolstoy's personal and intellectual journey which led him to his virulent anticlericalism.

\subsection{Religion up to Anna Karenina}

The first remark to make is that, at least up to his mid-life "conversion" to Christianity, Tolstoy was not what might be considered as a very "religious" person. In his early adulthood, he was fond of gambling, drinking and visiting prostitutes (he later recalled that lifestyle with shame) ([25], pp. 22-25). He did not attend church "of [his] own accord" after the age of sixteen, and "no longer believed" the religious teaching he had received as a child ([25], p. 21). His fictional writings did not deny that the clergy held an important place in the traditional canvass of Russian society, but he personally felt quite indifferent to what it preached.

At the same time, Tolstoy did experience moments of awe at Creation-of wonder for the natural world as well as of fascination for the rise and fall of civilisations. He did not necessarily see a providential hand behind it, but he did strive to understand what moved it. His earlier reflections on the mechanics of history, however, posited no agency behind it-neither divine nor human. He explicitly explained that he wrote War and Peace to demonstrate that "great men" have far less influence over the course of history than the countless fairly random activities of the little people who make up societies and armies $[22,26]$. There is no God overseeing human history any more than the evolution of Creation, though there is plenty to contemplate with awe in both nature and human society.

Tellingly, the thinker who had the biggest impact on Tolstoy in his formative years, and to whom Tolstoy regularly returned later in life, is Jean-Jacques Rousseau (see, for instance: $[27,28]$ ). He admired Rousseau enough to carry, at the age of fifteen, a medallion with a portrait of him around his neck ([29], p. 106). More to the point, Rousseauian themes reverberate throughout Tolstoy's corpus, be that in his critique of the establishment, in his pedagogical experiments, in the place of love and compassion in his political thought, or in his views on religion. In Rousseau, Tolstoy found a writer 
who anticipated his thoughts, an intellectual who made an impact, a seeker of truth unafraid of the scornful reception which his ideas would face in circles of power.

With regards to religion, arguably echoing Rousseau's remarks on the importance of religion in fostering social cohesion, Tolstoy famously jotted down the following comment in his diary in March 1855:

Yesterday a conversation about divinity and faith inspired me with a great idea, a stupendous idea, to the realisation of which I feel capable of devoting my life. This idea is the founding of a new religion appropriate to the stage of development of mankind-the religion of Christ, but purged of beliefs and mysticism, a practical religion, not promising future bliss but giving bliss on earth. [...] Consciously to work towards the union of mankind by religion is the basis of the idea I hope will absorb me. ([30], p. 101).

Way before his "conversion" to Christianity, therefore, Tolstoy seemed to think religions could be artificially founded and was already suspicious of "beliefs and mysticism", yet he was also clearly aware of the potential for religion to unite people and bring them happiness. Hence, even though he was not particularly religious, Tolstoy did acknowledge the social function of religion and had a degree of fascination for it before the existential torment which drove him to embrace his particular interpretation of Christianity.

\subsection{Turning to Jesus}

Tolstoy had achieved family bliss and literary fame with War and Peace when he was writing Anna Karenina in the 1870s. He was, however, increasingly agonized about death and the meaning of life. It was not death as such that worried him, but the apparent meaninglessness of life given that death is to follow: he worried that the inevitability of death rendered all activities futile. This angst drove him to read broadly and research "all branches of knowledge", and for years, he says, he "found nothing" ([25], p. 34).

The breakthrough came around 1879, when he observed that the peasants on his estate, despite seeming all too aware of death, seemed to approach it with calm and serenity. An important factor, it seemed, was their faith. Tolstoy therefore resolved to study the Bible again to try to find the source of their serenity.

Quickly, however, he found many parts of Christian scriptures and dogmas difficult to believe and difficult to agree with. Tolstoy could only understand and ponder what appeared rational, physically plausible and logically defensible. Anything that appeared irrational in the Bible and in the church's teaching, he discounted or explained away on rational terms-as with some miracles, for instance, which he saw as allegories, not physically true. (For example, Tolstoy read the miracle of the feeding of the multitudes as not about the actual multiplication of the fish and the bread, but as Jesus simply bidding the people to share food with one another. Similarly, the curing of the blind man becomes the mere elucidation of Jesus' teaching to a man who was hitherto ignorant ([31], pp. 179, 206-7).

As the next subsection will elaborate in more detail, Tolstoy could therefore be classified as a deist. He effectively reduced religion to morality, and from its cosmology could only keep what he deemed to make rational sense. He thus took from Christianity the moral teaching and example of Jesus, but not the resurrection, the miracles, the virgin birth and so on. He furthermore studied the teaching of other religious traditions, and again could only understand what seemed rational in them-mostly their moral teaching. According to Tolstoy, "religions differ in their external forms but they are all alike in their fundamental principles," which are:

that there is a God, the origin of all things; that in man dwells a spark from that Divine Origin, which man can increase or decrease in himself by his way of living; that to increase this divine spark man must suppress his passions and increase love in himself; and that the practical means to attain this result is to do to others as you would they should do to you ([32], pp. 271-72). 
Nonetheless, even though the central ethical teaching of all religions is some version of the "Golden Rule", for Tolstoy the most eloquent version of this common moral teaching is Jesus', especially in the Sermon on the Mount (for an application of Tolstoy's understanding of the Golden Rule to twenty-first century challenges, see [33]).

Tolstoy had long been concerned by violence, by war, by the meaning of life and by questions about how to best live it. The way he read Jesus' teaching provided him with an analysis and a solution to these worries, by giving meaning to a life "centered around the well-being of others" ([34], p. 56). Jesus convinced him that violence was always wrong and counter-productive, and that a strict pacifism had to lead to an anarchist rejection of the state given that the state is founded on violence and perpetrates it daily. Jesus led Tolstoy to a pacifism so absolute that it dissolved any possible legitimacy for state violence. This, he thought, was an unavoidable implication of the teaching expounded by Jesus most eloquently in the Sermon on the Mount but also in all of his frequent sayings on love and forgiveness, as well as in the way he embodied that teaching in his life and death ([35], chap. 1-2).

\subsection{Tolstoy's Metaphysics}

One might ask how this really resolved his existential angst. Tolstoy's explanations are rather elusive. On Life (1887) is probably his most substantial attempt at explaining his new metaphysical understanding systematically, yet as commentators have noted, it fails to convince due to significant inconsistencies and evasions [10,11,36,37]. A Confession (1879) and What I Believe (1884) are the other substantial texts in which Tolstoy elaborates his metaphysics, but here again, Tolstoy's argument is eccentric $([2,7,38]$, chap. $2 ;[39,40]$, chap. 13). Something that contributes to sowing confusion is Tolstoy's unconventional use of traditional Christian concepts. To illustrate this, one needs to briefly take a detour through some of Tolstoy's explanations.

In his metaphysical texts, Tolstoy frequently evokes a distinction between the "finite" and the "infinite", and claims that whereas the former can be analysed using rational knowledge, the latter can only be believed in. In Chapter 9 of his Confession, Tolstoy explains that what proved to be the crucial move that helped him out of his existential torment was the realisation that he "could find nothing along the path of rational knowledge, other than negation of life" ([25], p. 50) because it turned out he had been looking for "a demand for an explanation of the finite by means of the infinite and vice versa" ([25], p. 52). In other words, strictly rational knowledge could not give an "imperishable" purpose to a life which is inevitably "perishable" ([41], p. 83). Tolstoy then says that this compelled him "to recognize that all living humanity had a certain other irrational knowledge, faith, which made it possible to live" ([42], p. 53)—hence the metaphysical importance of the aforementioned introduction of faith in resolving his existential angst. At the philosophical level, faith allowed Tolstoy to make a bridge between the finite and the infinite.

What exactly, then, is "faith" for Tolstoy? He replies rather elusively that it is "the knowledge of the meaning of human life, in consequence of which man did not destroy himself, but lived. Faith is the force of life. If a man lives, then he must believe in something." ([42], p. 53) Tolstoy even portrays Jesus as having said that faith "is a clear understanding of what life is" ([43], p. 388). Tolstoy's logic here is frustratingly circular: faith provides knowledge of the meaning of life, because it is the knowledge of the meaning of life. Tolstoy accepts that this knowledge is "irrational", but at least it has "the advantage of introducing to every answer a relationship between the finite and the infinite, without which there can be no solution" ([25], p. 53).

Where does this understanding of faith leave reason? Tolstoy insists that "true faith is never irrational or incompatible with present-day knowledge", that "the assertions of true faith, though they cannot be proved, never contain anything contrary to reason" ([32], p. 245). As Guseinov explains, Tolstoy sees "faith" as "the foundation and limit of reason", as "that which bestows rationality on reason", yet:

Faith in itself is rational. [...] Reason exists above all to support faith. [...] If it were not for faith, for the question of why and how one should live, and for the necessity to answer 
this question according to concrete conditions in the constantly changing world, then the general purpose of reason would be incomprehensible ([4], p. 92).

Reason helps make sense of the finite world and ultimately even justifies faith, whilst faith gives reason a purpose. In a similar vein, Tolstoy defines "revelation" as follows:

I call revelation that which opens out to us, when reason has reached its utmost limit, the contemplation of what is divine, that is, of truth that is superior to our reason. I call revelation that which gives an answer to the question, insoluble by reason, which brought me to despair and almost to suicide — the question: What meaning has my life? [...] The answer must be such that though its essence may be incomprehensible in itself (as is the essence of God) all the deductions derived from its consequences should correspond to every command of reason, and the meaning it ascribes to my life should solve all my questions as to how to live ([44], p. 102).

Tolstoy therefore does give faith a central role, but its content remains mysterious, and reason anyway retains paramount importance in making sense of everything but the ultimate meaning of it all. He states it clearly enough: "Man has received from God only one instrument wherewith to know himself and to know his relation to the universe-he has no other-and that instrument is reason" ([45], p. 200). Indeed according to Tolstoy, Jesus teaches us to prize "the light of reason" above all else ([46], p. 203). Faith is necessary to give reason its purpose, but reason remains our only guide through the finite world.

What place and character does God then have in Tolstoy's metaphysics, especially since it is impossible, according to Tolstoy, to grasp the infinite using reason within the finite world? In Tolstoy's own translation of the Gospel, John the Baptist does say that: "God is a spirit; He cannot be measured and cannot be proved" ([31], p. 149). Nevertheless, further down, Tolstoy puts the following words in Jesus' mouth:

Every man, though he realizes that he was conceived by a bodily father in his mother's womb, is conscious also that he has within him a spirit that is free, intelligent, and independent of the body.

That eternal spirit proceeding from the infinite, is the origin of all and is what we call God ([31], pp. 267-68, [emphasis added]).

In other words, God is an eternal spirit some derivative of which is also somehow within us. In fact, Tolstoy frequently (and controversially) calls this very derivative of God in us all "Son of man" or "Son of God" ([31], pp. 142, 156, 239, 257, 266, 293; [46], pp. 110-12, 126), even "Christ" ([31], pp. 233, 289). For Tolstoy, this "spirit" is "something heavenly" in us all, something that "lives in freedom and reason" ([31], p. 155). It is also "the light in which men are to walk" ([46], p. 112). Indeed Tolstoy disputes the traditional understanding of "resurrection" and instead uses the term to evoke a "restoration of life" and the "exaltation of the 'Son of man'"- as defined by Tolstoy ([46], p. 128). As for God, Tolstoy sees life as "the offspring of the Father's spirit" ([31], p. 271), and God therefore as "that whole of which we acknowledge ourselves to be a part" ([47], p. xxii). Hence God is a deistic Origin of all that has given us life, a mysterious spirit a spark of which lives in us all. Clearly, therefore, Tolstoy does embrace the traditional vocabulary of Christianity, but his understanding of those conventional terms is unconventional.

Finally, in light of this, how does Tolstoy define religion? According to Tolstoy, "true religion" is "a relation, accordant with reason and knowledge, which man establishes with the infinite life surrounding him, and it is such as binds his life to that infinity and guides his conduct" ([32], p. 233). From this relation with the infinite follows a purpose, as do practical rules of conduct-an "ever-present guide to life" ([48], p. 198), a holy morality. Hence for Tolstoy morality "is implicit (impliquée, as the French say) in religion" ([48], p. 188). Religion provides human beings with moral guidelines 
for action in order to bring them into harmony with their faith, so that the life they lead can be meaningful—despite that meaning ultimately remaining unfathomable.

What Tolstoy's metaphysical gymnastics therefore allows him to do is: to close off all existential questioning by accepting that what meaning there must be has to ultimately remain mysterious; to nonetheless hold tightly to reason as a guide to analyse all there is in the finite world (including, as explained below, church theology, dogmas and rituals); and to elevate adherence to moral guidelines (that is, those spelt out by Jesus based on love and compassion) as the crucial choice facing those who wish to give their life meaning. It is no surprise therefore that Orwin observes that "Tolstoy's Christianity was ethical and anti-metaphysical" ([34], p. 56), that "Tolstoy's religious beliefs [...] are based on ethics rather than dogma", adding that "ethics replaces dogma or theology as the only real proof of the existence of God in Tolstoyan religion", because when we act ethically, "we are responding to the eternal truths within us, and to this extent, temporarily and through our subjectivity, escaping death" ([49], p. 233). As Hamburg puts it, "According to Tolstoy, if one lives one's life rationally-that is, altruistically-then a kind of immortality may be achievable" ([5], p. 140). Tolstoy thus borrows conventional religious vocabulary but only within the idiosyncratic grammar of his particular deistic and rationalistic metaphysics. The result is a philosophy which is only loosely rooted in traditional Christian understanding, and which exalts a rationalistic understanding of Jesus' ethics.

\subsection{Turning Away from the Church}

Whatever we make of Tolstoy's metaphysics, it opened the road for him to "discover" Jesus teaching-a discovery the importance of which for Tolstoy it is hard to minimise. Moreover, precisely because it was so important, Tolstoy was at first bemused and soon angered by what he saw as its belittling by the very authorities which claim to be the appointed apostles of that teaching. To borrow the vocabulary of a later Christian anarchist (Peter Maurin), for Tolstoy this message was "dynamite" which the church had disloyally "wrapped up, [...] placed [...] in a [...] container" and "sat on" ([50], p. 3). Having unearthed that dynamite, Tolstoy wanted everyone to do the same, and was outraged that the church had been trying hard to hide it.

In his Confession, Tolstoy claims that at least to begin with, he made a genuine attempt to understand and work with the church, its dogmas and its rituals-even becoming a regular at his local church. But, he says, he was increasingly turned away from it. As Spence observes, though Tolstoy envied the peasants their simple faith, "It was as if he had been given some jewels in a bag of stinking $\operatorname{dirt}^{\prime \prime}([11]$, p. 13). He could not square the teaching of Jesus with the broader teaching of the clergy, he could not see the connection between church rituals and the upholding of Jesus' morality, and he grew increasingly suspicious of the motives behind these discrepancies. The final straw was the church's blessing of Russian troops heading to war with Turkey ([25], pp. 67-76). This proved beyond doubt that the church was not interested in Jesus' teaching.

Thereafter, Tolstoy turned ever more critical of the church-particularly the Russian Orthodox Church since it was closest to him, but also any other Christian church which in becoming comfortable had increasingly soft-peddled and eventually stopped preaching Jesus' teaching and trying to live up to it. Tolstoy did acknowledge that some clerics and some churches try harder than others, and praised those who have striven to adopt Jesus' demanding morality - his favourite examples included early Christians and several Church Fathers (such as Tertullian and Origen), individual dissenters such as Peter Chelčický and William Lloyd Garrison, Reformation offshoots such as the Quakers and the Mennonites, and contemporaries such as the Doukhobors (a sect of Russian dissenters to whom Tolstoy's attention was drawn due to their radical pacifism) and Christian conscientious objectors ([51], pp. 187-90; [52], chap. 1). But he poured scorn on those who claimed to be followers of Jesus yet ignored his clear ethical instructions.

Tolstoy also sometimes appealed directly to the clergy and encouraged its members to return to a more honest preaching of Jesus' teaching. Some pages in What I Believe implicitly challenged the clergy to prove why his interpretation should be wrong. The reactions he received were predictably 
mostly critical, and he discussed and dismissed several of them in The Kingdom of God Is within You (1893) ([52], esp. chap. 2-3).

Tolstoy published his third main novel, Resurrection, in 1899 to help fund the migration of the Doukhobors to Canada, even though he felt it needed more work. His depiction of the enactment of the Eucharist in Chapters 39-40 of Part One uses the classic Tolstoyan literary technique of "defamiliarisation" - that is, looking at the world through the eyes of a child "as if for the first time, in a manner unencumbered by any preconceived notions of it", innocently unaware of social habits ([53], p. 34; [54], pp. 163-65) - to ridicule the whole event and the sanctimonious pretence of the church and state authorities administering it. The Russian censor was not impressed: the redacted version of the two full chapters was compressed to only these words: "The service began" ([55], p. 13).

Resurrection also finally sealed Tolstoy's excommunication from the Russian Orthodox Church. In response, Tolstoy published both a further "Appeal to the Clergy" (1902) for it to teach Jesus' teaching more honestly, and "A Reply to the Synod's Edict of Excommunication, and to Letters Received by Me Concerning It" (1901), in which he responds to each of the accusations levelled in the edict, and argues that what he believes in is what Jesus preached, whereas the church's teaching is but sorcery, deception and blasphemy [56,57].

In 1910, as the world media was relaying news that Tolstoy had fallen ill and was probably on his deathbed at Astapovo station, the Russian church despatched an envoy to magnanimously readmit a repentant Tolstoy back into communion, but he was not allowed into Tolstoy's bedroom ([23], p. 29). Tolstoy was convinced that the church was a fraud and his imminent death would not change his mind. He was happier excommunicated. He was buried, at his request, not in a cemetery but by a certain ravine on his estate where laid a mythical green stick on which his brother had told him in his childhood that the secret of happiness had been graved.

\section{Tolstoy's Anticlericalism}

Tolstoy's accusations against the church are many, and despite common objections to his analysis, his criticisms of religious institutions are not as out-dated today as might seem at first sight.

\subsection{Tolstoy's Charges}

It is already clear from the above that Tolstoy's central charge against the church is that it has belied and betrayed Jesus' teaching and its mission-a message he is eager for Christians in particular to hear.

For Tolstoy, this betrayal of Jesus is typified by Emperor Constantine's "conversion" to Christianity, when instead of adapting the empire to Christianity, Constantine and his accomplices adapted Christianity beyond recognition to suit their interests ([51], esp. pp. 187-90; [52], p. 62; [58,59]). Tolstoy is not claiming that Constantine's act alone single-handedly corrupted Christianity-he traces deviation from Jesus' teaching right back to Paul, and sees later church Councils such as that of Nicaea as pivotal in cementing the cooptation of Christianity by the empire-but he still depicts Constantine's conversion as a telling illustration of how far official Christianity twisted Jesus' original message. Ever since that conversion, the mainstream church has cuddled with state power, legitimising whatever regime happens to be protecting it in exchange. It might be portraying itself as the body of Christ, but it is in fact working against Christ.

Tolstoy also slates the sanctimonious tone with which the church preaches its corrupted interpretation. For instance, Tolstoy denounces the alleged infallibility of the church and of the Bible: the latter, for him, is just a large collection of writings from very different authors cobbled together and tinkered with time and time again (within which somehow still nonetheless survive, squeezed but shining, the important Gospel gems of Jesus' teaching); the former is just a collection of men as likely to be fallible as any other ([32], pp. 238-41; [44], pp. 104-5; [52], chap. 2; [60], p. 207; [61], pp. 313-16).

Tolstoy is particularly dismissive of the various ways through which church theologians reduce the importance of Jesus' most important commandments. Tolstoy expects those who claim to follow 
Jesus to follow his teaching and example. Like other Christian radicals, he is therefore scathing of much of the official church for not doing so, indeed for even wilfully discounting the uncomfortable parts of Jesus' ethics and distracting its flock with fantastic dogmas and stupefying rituals $[46,52,56]$. For Tolstoy, this amounts to a cowardly and despicable betrayal of the core teaching of the one who Christians call their messiah. Tolstoy's strong language attests to the extent to which he feels the church has betrayed its original (and important) mission—-to teach and exemplify Jesus' radical morality.

Tolstoy further accuses the church of deploying a broad arsenal of mental trickery to distract the masses from that morality, including: the idea that miracles somehow provide proof of church creeds; the focus on external worship in which impossible propositions are repeated robotically; the deliberate mixing of truths with falsehoods in order to drown the former in the latter; and the way in which all this combines to stifle reason and basically amounts to carefully planned hypnotism ([46,52,56-58]). All this, according to Tolstoy, is calculated precisely to dilute Jesus' revolutionary morality. Thus, even though Tolstoy's primary accusation concerns the corruption of Jesus' teaching, in the process, Tolstoy also comes to dismiss the theology, dogmas and rituals which he reckons cannot withstand the test of rational scrutiny.

According to Tolstoy, "The essence of religion consists solely in the answer to the question, 'Why do I live, and what is my relation to the infinite universe around me?'" ([48], p. 173) Indeed he claims that "There is no religion from the most elevated to the coarsest that has not at its root this establishing of man's relation to the surrounding universe or to its first cause" ([48], p. 173). Moreover, as explained above, for Tolstoy "morality is the ever-present guide to life, which results from that relation" ([48], p. 198) and this morality has to be "accordant with reason and knowledge" ([32], p. 233). Therefore "the supposition that reason cannot be applied to the solution of religious questions [...] is as strange and as obviously false as the supposition that calculation cannot solve mathematical questions" ([45], p. 200). Reason is our only tool to understand religious propositions. To stifle or downgrade it is suspicious and dangerous.

In his short, caustic yet amusing "The Restoration of Hell" (1903), Tolstoy portrays a fictional conversation between Beelzebub and his little devils where these devils must gradually convince their boss that their cause is actually not lost even though Jesus' clear and simple teaching should have rendered them unemployed for good. Beelzebub finds this very hard to believe, but one of the devils steadily explains how he invented "the Church" and thereby eventually restored their cherished Hell ([61], pp. 311-16). "What is 'the Church'?" asks Beelzebub. The devil replies:

Well, when people tell lies and feel that they won't be believed, they always call God to witness, and say: "By God, what I say is true!" That, in substance, is "the Church", but with this peculiarity, that those who recognize themselves as being "the Church" become convinced that they cannot err, and so whatever nonsense they may utter they can never recant it. The Church is constituted in this way: Men assure themselves that their teacher, God, to ensure that the law he revealed to men should not be misinterpreted, has given power to certain men, who, with those to whom they transfer this power, can alone correctly interpret his teaching. So these men, who call themselves "the Church," regard themselves as holding the truth not because what they preach is true but because they consider themselves the only true successors of the disciples of the disciples of the disciples, and finally the disciples of the teacher-God-himself ([61], pp. 313-14).

The tenet that postulates the Bible and/or the church to be infallible is for Tolstoy utterly preposterous: it is illogical and leads to absurd conclusions. Besides, in its teaching and practice, the church wilfully fails to give proper prominence to the "true religion" and morality preached by Jesus. It claims direct lineage to Jesus yet is the main obstacle to the propagation of his teaching. For Tolstoy, it is a fraud, and needs to be denounced as such.

It should be clear by now that what is here called Tolstoy's "anticlericalism" therefore consists of a series of charges laid against the Russian Orthodox Church of his time in particular, but also more 
generally against the mainline, orthodox, established "church" since Constantine-at least to the extent that what Tolstoy dislikes in the Russian Church can be found in other context-specific instances of the mainline "church". Tolstoy's anticlericalism also applies just as much to newer post-Reformation churches if and when they can be accused of the above, including therefore any church that might have started as a movement focused on returning to Jesus' ethics but which then drifted away from that focus as it became increasingly institutionalised. In any case, Tolstoy's opposition was to the church, not to religion (as he understood it): Tolstoy's ire is focused at the institution, not the phenomenon it claims to be an institutionalisation of, hence the label of "anticlericalism" rather than "anti-religion" or "atheism" to describe Tolstoy's charges.

One could summarise Tolstoy's anticlericalism as making two separate but related types of accusations against the church: one about the abstract truth or otherwise of what is preached, the other about the hypocrisy with which falsities come to dominate the preaching. That is, firstly, Tolstoy cannot reconcile the church's theology with his own metaphysics (and corollary prioritisation of morality). Tolstoy's metaphysics may not be as epistemologically rigorous as he imagines and undeniably contains some rather peculiar twists, but either way he finds church theology to be irrational (and epistemologically less well grounded in Jesus' authentic message than his ethical prescriptions). Secondly and moreover, Tolstoy accuses clerics of (at best) losing sight of, and (at worst) wilfully underplaying, Jesus' ethical instructions as they get carried away by the deluded pursuit of metaphysical fantasies. That is, Tolstoy accuses the church not only of preaching a metaphysics which makes no rational sense, but also of busying itself with deluded metaphysical pursuits instead of prioritising the ethical teaching which it was ostensibly founded to spread. Indeed the two accusations are linked: the increasing overemphasis on metaphysical claims diverts time, energy and attention away from ethical priorities, and at least some of those who encourage this diversion do so quite knowingly and wilfully. In short, for Tolstoy, what the church teaches is false, and teaching it has increasingly distracted it from its original mission.

\subsection{Common Objections}

Tolstoy's views on religion have been embraced by some but also criticised by others, whether through passing dismissal or more dedicated denial. These criticisms cannot all be recounted and discussed here, but it is worth considering those which might still appear to carry most import today.

One set of criticisms centres around Tolstoy's reliance on "reason" to dissect Christianity. Tolstoy's account of religion, the argument goes, was too crudely rationalistic and too simplistic $[3,7,10,11,23,38-40,55,62-67]$. His dismissal of the resurrection in particular means to some that he cannot be considered a "Christian", because he denies a central tenet of that faith-one which in fact played a crucial role in the early spread of Christianity. Besides, the exaltation of "reason" typical of Enlightenment thought has come to be criticised more recently (by arguments stemming from a variety of perspectives including post-positivist, post-colonial and post-structuralist schools of thought) for the questionable nature of "universality" and because such claims to universalism are seen by some as a form of neo-colonial imperialism.

Nevertheless, the momentous achievements of science are based on and verified by what can, with some epistemological justification, be labelled "reason". It is true that "reason" has too often been used as an excuse to impose ethnocentric or imperialistic policies instead of respecting local traditions (and this should be acknowledged and avoided), yet, as Enlightenment thought asks, what other tool have we against superstitions, obscurantism, and other threatening ghosts whose harm litters the annals of history? Is one of the central aims of education not to foster a critical and rational mind? Indeed how unpopular really today is what nineteenth-century thinkers meant by "reason"? Do many critical citizens not use such "reason" to measure claims thrown at them? The critique of "reason" and "rationalism" articulated by critical scholarship in recent decades is rich and genuinely important, but even if it convincingly demonstrates that arguments founded on reason are not "universally" applicable, the reflections articulated by rationalist thinkers such as Tolstoy remain pertinent and applicable in at 
least some, perhaps many, historical contexts. That Tolstoy might have elevated "reason" further than preferable for more recent critical scholarship need not invalidate his claims in all past and present political contexts.

Besides, in terms of using reason as a filter to make sense of religion, for Tolstoy: "To say that a man should not be guided by reason, is the same as to say to a man carrying a lamp in a dark catacomb that to find the way out he must extinguish his lamp and be guided, not by light but by something else" ([45], p. 201). In fact, for Tolstoy, that the "divine" light of reason resides in us all is what religious prophets have been teaching for centuries ([46], p. 112). It could also of course be argued that not all existing Christian scholarship need be dismissed, that some studies can help understand the context and meaning of Jesus' teaching, and indeed that Tolstoy does find help in some such studies for his own analysis (whether he fully acknowledges it or not). Besides, several other Christian anarchists have provided precisely such a more measured engagement with some of the tradition and thereby strengthened the Christian anarchist thesis where Tolstoyan intransigence makes it more difficult to accept [35]. Tolstoy's exaltation of reason is unusual even among Christian anarchists, and perhaps Tolstoy went quite far in dismissing all of Christianity that he judged to be irrational, but he is nonetheless not alone in adopting this kind of approach. Numerous agnostics and atheists will be sympathetic, as will indeed those Christians who are minded to filter some of the traditional package of Christianity in light of evolving science. Tolstoy's rationalism might be fairly extreme, but rationalistic approaches are still adopted by many nowadays (even if at times only in all-but-name).

Another criticism levelled at Tolstoy is that religion should not be reduced so tightly to morality [7,38-40,52,65,68-71]. Moral guidelines are important aspects of all religious traditions, but there is much more to religion than puritanical morality, and Tolstoy is guilty of ignoring all those other aspects that make religions richer than a mere moral code can be. Nonetheless, ethical concerns are quite central to religion. Every religious tradition advocates certain types of behaviour and frowns upon others. There may well be much more to Christianity than the moral teaching of Jesus, but that teaching is part of it too. Tolstoy might rightly be accused of ignoring or dismissing many Christian dogmas, but then could many avowed Christians today not conversely be accused of ignoring or dismissing Jesus' moral teaching? Tolstoy's views on the facets of Christianity which he dismissed may not stir every Christian's interests, but what he does say about Jesus' moral teaching is still worth paying some attention to, because it is central to both the Christian story and, according to Tolstoy anyway, actually rather rational and wise.

Another argument put forth by critics of Tolstoy's anticlericalism is that not all institutional Christianity is that noxious, and that the Russian Orthodox Church in Tsarist Russia was a particularly pronounced-but infrequent—case of what he criticised [7,9,38,72-74]. There have also been many examples of Christian groups across time and place that were much closer to Jesus' teaching than the mainline church-indeed Tolstoy recognised and praised these, as noted above. Nevertheless, much mainstream Christianity does tend to come close to what Tolstoy criticises. Moreover, with time, many of even the more radical Christian sects which Tolstoy praised made compromises, became comfortable and gradually lost their radical aspirations. In other words, as discussed further below, a process of institutionalisation does seem to systematically dampen the originally more radical offshoots of Christianity.

\subsection{Tolstoyan Anticlericalism Today}

It may seem when watching from much of Western Europe today that anticlericalism has become largely redundant-religion, it is said, has been losing influence as society has gradually secularised. Yet, as recent scholarship on "postsecularity" (for example) has argued, it seems premature to expect religion to disappear in the way much Enlightenment thought had expected it to (For instance: [75-77]).

For a start, even in Western European countries—-those often cited as the most secularised-state and church are rarely fully separated. A significant degree of institutional secularisation has undeniably 
taken hold, and public debates are hardly ever settled by appeals to religious truths anymore. Church and state have been separated to a degree Enlightenment thinkers could only hope for. Despite this, however, in some European countries, the subsistence of the clergy is funded by the state; in others, Christian "heritage" forms an integral part of national identity (church property might be maintained and preserved by state funds, for instance); in many, the symbols and iconography of one are present in the other; and so on. In short, religion still influences politics and vice versa, even in much of Western Europe (see for instance: [78-80]). The pact between church and state which Tolstoy criticised so vehemently still persists to a non-negligible degree.

This is even truer outside Western Europe-not least in Tolstoy's own country. The clergy remains powerful and influential in much of the Christian world (as indeed do religious figures in other religious traditions). In other words, despite a degree of secularisation in Western Europe, much of what Tolstoy said about institutionalised Christianity is no less apposite today than it might have been in Tolstoy's context. Indeed, church theologians continue to cite many of the arguments mocked by Tolstoy to justify Christian submission to the established political and economic regime.

At the same time, a considerable number of (in particular, but not only) Westerners have become visibly disillusioned by "institutional" Christianity, especially since the Second World War. Whilst scholars still debate the extent of secularisation in the West, there is broad agreement that religiosity has evolved. Many have turned away from church attendance and been attracted by new, more personal, expressions of spirituality [78,80-83] —and Tolstoy's critique of the church may well resonate with the views of those who have consciously moved away from the church, as well as with atheists and religious sceptics. That said, Tolstoy was not interested in spirituality but in morality. For him, the metaphysical or cosmological claims of religious traditions were less interesting than their relatively similar morality.

In any case, it seems likely that Tolstoy would wish to reiterate his arguments to those who consider themselves Christians today. His writings (including his detailed exegesis) invite Christians to reconsider Jesus' teaching anew, to question or bypass the exegesis traditionally preached from church pulpits and make up their own mind on whether Jesus did not quite clearly and deliberately call his followers to exemplify the radical morality he preached. Tolstoy might be an eccentric and anticlerical Christian thinker, but he contributes to Christian thought nonetheless. The main reason he was so hostile to the church was because he felt that it was diluting, dismissing and ignoring the very essence of Jesus' teaching. There is every chance he would feel similarly today, though he would praise and encourage those Christians who question the veracity of the affluent church's interpretation and who try to wholeheartedly follow Jesus' teaching and example. In short, Tolstoy's anticlericalism is not as dated or limited to its narrow context as might seem. It is addressed primarily to Christians, for them to become more Christ-like and more critical of the self-appointed official intermediaries of God on Earth.

\section{Extending Tolstoyan Anticlericalism beyond the Church}

The core of Tolstoy's analysis, however, is arguably applicable even more broadly than this. That is, over and above his critique of the church, the reflections and arguments which informed Tolstoy's anticlericalism are potentially relevant not only for the church. In other words, I want to propose that part of the appeal of Tolstoyan anticlericalism is that the arguments behind it can be applied to secular phenomena too. Tolstoy himself of course also separately criticised hierarchies other than the church, such as the penal system, the army and even the canonical approach to literature $[20,25,52,84,85]$, however what I want to focus on here are the arguments he employed specifically against the church, but in order to then apply them to phenomena other than the church.

\subsection{The Torch of Rational Scrutiny}

One such extension which is fairly straightforward yet which Tolstoy would presumably insist on would be a call to remain sceptical of all forms of preaching, especially when grounded in questionable 
arguments-but not only when stemming from religion. The same critical scrutiny of self-assured assertions which Tolstoy applied to church teaching, he would counsel against secular self-assured assertions too. No degree of respectability through institutionalisation, of robotic repetition through regular rituals, or of shielding behind tradition should exempt secular claims from critical scrutiny. Moreover, any claim should be particularly distrusted when its affirmation is tainted in scaremongering, glorified tales of superiority, and other such emotional lures.

This may sound quite banal, but we do not need to search too long in the speeches of certain politicians, in the tenets of certain ideologies, or in the scaremongering of certain media outlets to find the sort of sanctimonious yet logically poor preaching, which Tolstoy despised in the church, now in secularised form. Consider the predictions of doom if too many immigrants flood in, if more red tape stifles "free" enterprise, if this or that political rival wins the next election, or if we do not employ military might against this or that threat from people with views different to ours. Consider too the glorified histories we repeat to ourselves about our particular people, our particular past, and how this has led to the glorious political institutions we should not be too critical of. Consider all these messages reaching us through the media, and indeed consider the role of media corporations in propagating them. Do these messages not mix truth with falsehood and stir up our emotions much like the church teaching Tolstoy despised? And how different are mainline media institutions to the mainstream institutional churches criticised by Tolstoy-whether in their function or in their relationship with political and economic establishments?

Of course, just as with the churches Tolstoy commented on, there are some examples of honest practitioners. However, the public sphere is awash with preachers resorting to poor arguments, boastful praise and scaremongering who seek to whip the population into consenting to their calculated agenda in ways not dissimilar to the clerics despised by Tolstoy. And yet a public sphere in which political decisions are discussed thoroughly and rationally is a central precondition in all theories of functioning democracy. When public discussions are infested by deceptive tactics and apathy for reasoned analysis, the public sphere is quickly owned by demagogues.

In Tolstoy's days, the pulpit was still one of the traditional channels of communication and education for the masses-although this was already changing fast with the rise of literacy, mass media and new forms of communication [86-88]. Churches in many parts of Europe are emptier nowadays than centuries ago, yet the type of preaching through traditional church channels which Tolstoy was suspicious of is comparable to that reaching us through our media. Indeed, one of the drivers of secularisation is the supplanting of religion with secular alternatives: in secularised societies, the functions previously performed by religion are performed by secular processes, rituals and institutions $[89,90]$. Equally though, the same disingenuous preaching denounced by Tolstoy arguably persists in secularised form, beaming out of the cathedrals of orthodox opinion-the same suspicious methods by which seemingly quaint religious claims were spread up to Tolstoy's days can be employed for secular claims.

Yet if this comparison holds, are all snappy critics of religious charlatanism as quick to denounce the same (secularised) charlatanism in today's secular preachers? It does not seem far-fetched to expect that Tolstoy today would apply with the same doggedness some of the arguments of his anticlericalism to all those who, through the media, seek to manufacture consent for their view yet—crucially—flee or ridicule the scrutiny of reason or honest critical analysis. Tolstoy would no doubt reserve particular scorn for those embracing marketing techniques to shape popular preferences, because these techniques precisely seek to create irrational emotional bonds to products, brands and increasingly political parties and views, directly undermining the role of reason through manufactured emotions.

Now, this sort of critique of the manipulation of the masses is not new. Numerous other anarchist, Marxist and other critical scholars have elaborated precisely the sort of critical scrutiny of the political economy, of the media and of unscrupulous preachers called for here. I am not claiming that Tolstoy's reflections are richer than theirs (they are not) - after all, his main focus is limited to the church, the state and the revolutionary methods of his context. What I am simply trying to draw attention to is 
that the relentless and specific critique he elaborated of the church need not be restricted to the church. The church was the institution he had to confront directly given the arguments he was making in his context, but in today's different context the other institutions which have supplanted the church as leading distorters of reason nonetheless still display attributes similar to those Tolstoy criticised in the church. It is not sufficient, therefore, to limit any potential sympathy for Tolstoyan anticlericalism to critical scrutiny of the church only. At the root of Tolstoyan anticlericalism is a drive to scrutinise any source of distortion of reason. In short: Tolstoy's anticlericalism is primarily about consistent critical scrutiny, a scrutiny the application of which is not reserved for the church only.

Heavily influenced as he was by Enlightenment thinking, the vocabulary Tolstoy used was that of "reason" and its derivatives. Indeed Tolstoy sometimes uses terms such as "reason", "reasonable consciousness", "wisdom" and even "Logos" rather interchangeably-terms which in contemporary parlance might be akin to critical and/or rational scrutiny ([31], p. 135; [37], p. 46). Tolstoy saw this light of "reason" as the one thing all humans have in common, and hence prescribed its shining as the main tool to guard against manipulation by unscrupulous preachers. Whether or not some might prefer a different vocabulary, consistent campaigners against church preaching ought to scrutinise the claims advanced by secular preachers as passionately as they do with religious ones. Many anarchists do extend their anticlerical critique thus, but the same is not true of all atheists, humanists and religious sceptics. In a world where media-spinning, preference-manipulation and simplistic journalism are seen by many as perfectly acceptable professions, a Tolstoyan crusade against unscrupulous preaching would apply to all unscrupulous preaching, religious and secular.

\subsection{Knowing False Preachers by Their Fruits}

One of the motives behind Tolstoy's anticlericalism was his observation of the hypocritical distance between the moral teaching of Jesus, which the church officially preaches, and its practice. One reason Tolstoy admired Jesus was precisely that he practiced the demanding morality he preached-however challenging this proved to be. Jesus taught by word but also by example. This inspired Tolstoy to the extent that he even advocated exemplary behaviour (what many anarchists call "prefiguration") as the main revolutionary method, arguing that the virtuous morality of some could contagiously snowball into a radical reconfiguration of social relations. Here is not the place to examine Tolstoy's revolutionary theory in detail, but what is perhaps worth reflecting on a little further is that Tolstoy's criticism of the church, echoing somewhat Jesus' criticism of the clerics of his day, is partly informed by the church's failure to live up to the ideal which it preaches (even if it then suffocates it with further dogmas and rituals). Tolstoy therefore followed Jesus' advice about knowing false prophets by their fruits (Matt. 7:15-20), and on that basis was disdainful of the church.

By that measure, however, the church is not the only institution to merit disdain. Following Tolstoy, all teachers of morality ought to be tested by their adherence to that morality, including secular institutions. The same anticlerical logic which led Tolstoy to criticise the church therefore applies for instance to states preaching peace, justice, solidarity or democracy yet waging war, facilitating injustices, weakening solidarities or making a mockery of democratic principles. A country selling weapons to autocratic regimes, cutting the funding which allowed the poorest to defend themselves in court, eroding its safety net for the most deprived and maintaining an electoral system which prevents the emergence of dissenting parties could not, by this argument, claim to be a beacon of the values which its actions undermine. No amount of conventional self-congratulations for settling on the "least worst" system would do for Tolstoy. The commitment of institutions to further certain values, whether religious or secular, is measured by their practice. Here again, the argument feeding Tolstoyan anticlericalism extends to secular institutions.

The same is true of individuals: Tolstoy would apply the same scorn which he reserved for hypocritical clerics to politicians who do not practice what they preach and who do not do to others as they would like others to do to them. Given that the political classes articulate moral guidelines for all in society, an implicit corollary to the rule of practicing what one preaches would be the expectation 
that when lecturing people living in socio-economic conditions different to ours, we ought to practice living in those conditions before we resort to any moralising. As a minimum, Tolstoy would expect political elites to put their children in state schools, queue with fellow citizens for health treatments, use public transport and so on-in short, to experience the very configuration of public services which they preach. A few notable examples aside, such attitudes are very rare. This is not to mention some of the famous scandals where campaigners for certain moral attitudes were spectacularly found to indulge in what they sanctimoniously condemned. Yet those who lecture about morality without practicing it themselves are comparable to the clerics whom Tolstoy denounced. Tolstoy's criticism of this aspect of clerical hypocrisy applies as much to secular clerics as to religious ones.

Above all, for Tolstoy, any preacher of morality-whether an individual or an institution-ought to also practice that same morality. Tolstoy accused church clerics of hypocrisy for not practicing what they preached, but the same argument applies to staff constituting any other institution which advocates any particular morality, religious or secular.

\subsection{Secular "Clericalisation"}

There is another element of Tolstoy's anticlericalism which can arguably be "secularised" and extended beyond the analysis which Tolstoy limited himself to by focusing on the church. That is, perhaps one can label "clericalisation" the process of institutionalisation which so frequently ends up obscuring the original aim of an institution's founding prophets (on this, see also [91]).

This process has been observed in religious movements in seminal sociological studies such as Max Weber's on the "routinisation" of "charisma" and H. Richard Niebuhr's on the transformation of "sects" into "denominations", but arguably befalls all institutions-religious and secular ([92], pp. 26-39; [93], pp. 60-69). Even if what preceded the gradual Fall may never have been that bright and perfect an Eden, many religious offshoots that had been founded around particular charismatic figures and virtuous intentions lost some of that pioneering impulse within a few generations-despite perhaps still attracting converts in part precisely by appealing to that original impulse.

A similar process of transformation from an original impulse to a more self-serving institution arguably afflicts secular impulses and ideals. Indeed, have states founded on revolutionary ideals not gradually drifted away from the honest and consistent implementation of those ideals over time (actually, sometimes, rather quickly)? Do political institutions originally founded to further a particular vision not often end up instead prioritising their own institutional interests and welfare over the founding ideal (however much lip service they pay to it)? Do the self-appointed representatives of the original ideal not often disappoint precisely by their evident betrayal of that ideal?

Consider, for instance, the democratic ideal so foundational to Western identity: have those states which congratulate themselves for having embraced "democracy" out of a proud revolutionary moment really achieved the ideal which the commemorated revolutionaries envisioned? Is the effective functioning of the system which appoints people to power in our most advanced "democracies" not deeply distorted by vested interests, biased electoral systems, spin-doctoring and frequently depressingly superficial debates? In truth, real democracy seems to remain a rather elusive ideal still to be strived for, and the institutions that label themselves democratic offer a rather poor, possibly weakening, approximation of that ideal.

A similar analysis could be developed about the ideal of equality and comradeship and what became of it in formally "communist" regimes, or about the ideal of justice and the way it ends up being administered through even the most celebrated judicial systems. Perhaps a similar process of "clericalisation", i.e., of corruption of original ideal through institutionalisation, can be discerned in an even wider variety of examples-such as the actual functioning of the journalism industry compared to the ideal of speaking truth to power within a functioning public sphere, the reality of university life compared to the ideals of the academy, the transformation of political parties or non-governmental organisations from their initial mission to their evolving life as established players 
on the political landscape, or perhaps even (controversially for anarchists) the real use and purpose of policing compared to the notional ideal of keeping a just peace, and so on. Compare too the somewhat utopian ideal of communal living and the fate of many intentional communities.

What seems to happen to many laudable aims and ideals is that they end up lost and betrayed through a process which, taking our cue from Tolstoy's critique of the church, could be referred to as "clericalisation" - a process whereby institutions (religious or secular) tend to become agents which not only revise their commitment to their founding intentions, but which even often become major forces working against those. This may not happen to the same degree in all instances, and there may be cases where the more corrosive effects of clericalisation have been guarded against, but this process does seem to corrode many laudable intentions.

The parallel between religious and secular institutions can also be illustrated by returning to the two separate yet related types of Tolstoyan accusations against the church summarised above. Of course, Tolstoy's specific criticisms concerning the church's specific truth claims (the first set of accusations) are hardly applicable to other institutions, but those institutions do nonetheless often justify their raison d'être based on certain explicit or implicit claims about broader reality, human nature and/or iron laws of society-claims which may or may not always withstand closer critical scrutiny. Moreover, both within and around secular institutions, a significant amount of human energy can be spent in abstract ideological and philosophical discussions about those institutions (the second type of accusations). Furthermore, here again, the two separate aspects are arguably linked in that the time and effort spent in abstract discussions contributes, whether deliberately or inadvertently, to the very process of clericalisation. To take some of the examples mentioned above: drawn-out debates disputing amendments to a specific political structure's constitution, or disagreeing on the precise ideological blend to be captured in a party manifesto, or theorising and philosophising about the purpose of universities or media organisations, can all contribute to those institutions losing sight of their founding mission. This does not mean all philosophical discussions are necessarily corrupting - after all, Tolstoy himself needed to work out his metaphysics before he decided to focus squarely on morality. Nevertheless, extensive philosophising can divert efforts away from action, and the affliction alluded to by the proverbial bickering about how many angels can dance on a pinhead is one that can actually distract any institution, religious or secular, from the ideals it was originally founded to pursue.

Of course, numerous scholars have already commented on the gap between institutions' intentions and their practice, on the self-serving logic which takes hold of them and leads to abuses of power, on how institutions sooner or later succumb to an elite, and on the disastrous ossification which follows many a moment of political disruption. Numerous scholars have also noticed that radical religious movements have a tendency to become more rigid and conservative as they become established. What is rarely noticed however is the parallel between the process which transforms the early idealism of religious radicals and the same clericalising process with secular idealisms. This, I propose, is something that an argument emerging from the meeting of Tolstoyan anticlericalism with broader anarchist reflections on the nature of political institutions can provide.

Moreover, perhaps we can draw further inspiration from Tolstoy in denouncing such clericalising drift whenever we encounter it, and appealing to the conscience of those staffing those institutions to stay true to the founding ideal-however demanding or utopian this original commitment might seem. It is after all important to remember that in all the secular examples listed above, the self-appointed representatives of the founding ideal, i.e., the people who constitute the institutions, just like the clerics of the church, are all human beings with a conscience and an ability (if not always a willingness) to engage in reasoned discussion. However scathing he was of clerics, Tolstoy also appealed directly to them. However critical he was of soldiers, politicians, aristocrats, Christians, revolutionaries, etc., Tolstoy often addressed himself directly to them, appealing to their conscience, calling them to wake up to the reality of the distance between their effective practice and the arguably laudable ideal with which they justified their actions. In appealing to Christians, for instance, Tolstoy was trying to rekindle 
their passion for the teaching at the origin of their tradition. In appealing to the staff constituting "clericalised" institutions, with Tolstoy, we can try to rekindle the passion for the nominal impulse at the origin of that institution, the original aim which found itself de-prioritised as the institution became as self-serving as the churches criticised by Tolstoy. Unless "clerics" remain committed to the original impulse, the clericalised institution will quickly lose sight of its founding mission. Just as clergy can be truly inspiring when truly striving to embody Jesus' moral teaching, the same authenticity to the founding ideal in secular institutions can draw inspiration and respect.

This leads to an important question, which is: can laudable ideals be prevented from suffering this process of clericalisation? It is after all striking that so many ideals have suffered clericalisation. It is also therefore difficult to deny that clericalisation is a fairly potent and resilient process which it is consequently difficult to prevent. Perhaps one way to avoid it is to eschew "clergy", the army of professionals whose standing depends on the institutionalised creed. Yet where goals require some organisation in order to be achieved, structures are likely to emerge, and probably soon ossify. Anarchists here remind us of the many tools and techniques which can be employed to embed the kinds of bottom-up accountability, openness and malleability which can help prevent clericalisation. Yet even this also requires a combination of vigilance, of courage to denounce clericalisation, and a determination to remain authentic to the founding spirit. In other words, to guard against clericalisation, perhaps one needs to don the kind of dogged spirit exemplified by Tolstoy in his anticlericalism and apply it to all institutions, religious or secular.

\section{Conclusions}

Tolstoy's passionate denunciation of what has here been described as "clericalism" played no small role in the international fame he enjoyed in the last decades of his life. His Christian anarchist writings inspired many both in Russia and abroad, although many Tolstoyan communities either collapsed or, as with many individual followers of his, were persecuted and engulfed in the conflagrations of violence which befell the early twentieth century. Tolstoy himself famously tried to live up to what he preached, though just as famously not without difficulty. What he cannot be faulted for however is his drive to speak truth to power, both political and religious.

Tolstoy held at times rather eccentric views on religion, which have puzzled those who have been drawn to this notorious writer and critic. One of the original aims of this article was to summarise and discuss his criticisms of the church, as well as his idiosyncratic understanding of core Christian concepts. In the end, even if Tolstoy's anticlericalism is not that exceptional among free thinkers, it had a significant impact in his time. It also remains relevant today to the extent that established churches still display the sort of characteristics criticised by Tolstoy. Moreover, this article has also shown how the underlying arguments on the basis of which Tolstoy levelled his critique of religious institutions can be applied to secular institutions as well. In other words, interesting as it is to examine in detail the criticisms of the church of a towering figure like Tolstoy, it is also interesting to reflect on how the arguments behind this anticlericalism apply beyond his specific targets and context.

What happened to the mainstream church since Jesus is a process which arguably afflicts all institutions: the original purpose gets lost, forgotten or deliberately ignored as the institution set up to promote it takes a life of its own. If this analysis of "clericalisation" is accurate, then this is surely something for all those with any ideals to reflect upon-anarchists, feminists, democrats or anyone else minded to improve the human condition. It is painfully demoralising to see laudable ideals into which one has invested time and effort suffocate under the institutions set up to further them. The fate of Jesus' teaching provides one example among many. Conversely, however, perhaps Tolstoy provides an example of the commitment to critical scrutiny and stubborn denunciation with which all kinds of clericalism can—and should—-be confronted today. 
Acknowledgments: An earlier draft of this article was presented at the Enlightened Anarchism conference organised on 12-14 September 2014 at the University of Lapland, Rovaniemi, Finland, in cooperation with the University of Cambridge. The author is particularly grateful to Ali Jones and Mika Luoma-aho for organising the conference, to the many participants who provided helpful comments on the paper, as well as to the very helpful anonymous peer-reviewers whose comments hopefully improved the paper.

Conflicts of Interest: The author declares no conflict of interest.

\section{References}

1. Abraham, J. H. “The religious ideas and social philosophy of Tolstoy." International Journal of Ethics 40 (1929): 105-20. [CrossRef]

2. Flew, Antony. "Tolstoi and the meaning of life." Ethics: An International Journal of Social, Political, and Legal Philosophy 73 (1963): 110-18. [CrossRef]

3. Greenwood, E. B. “Tolstoy and religion." In New Essays on Tolstoy. Edited by Malcolm Jones. Cambridge: Cambridge University Press, 1978, pp. 149-74.

4. Guseinov, A. A. "Faith, God, and nonviolence in the teachings of Lev Tolstoy." Russian Studies in Philosophy 38 (1999): 89-103. [CrossRef]

5. Hamburg, G. M. “Tolstoy's spirituality.” In Anniversary Essays on Tolstoy. Edited by Donna Tussing Orwin. Cambridge: Cambridge University Press, 2010, pp. 138-58.

6. Kolstø, Pål. “A mass for a heretic? The controversy over lev Tolstoi's burial." Slavic Review 60 (2001): 75-95. [CrossRef]

7. Matual, David. Tolstoy's Translation of the Gospels: A Critical Study. Lewiston: Edwin Mellen, 1992.

8. Medzhibovskaya, Inessa. Tolstoy and the Religious Culture of His Time: A Biography of a Long Conversion, 1845-1887. Lanham: Lexington, 2008.

9. Rancour-Laferriere, Daniel. Tolstoy's Quest for God. London: Transaction, 2007.

10. Spence, G. W. “Tolstoy's dualism.” Russian Review 20 (1961): 217-31. [CrossRef]

11. Spence, G. W. Tolstoy the Ascetic. Edinburgh: Oliver and Boyd, 1967.

12. Weisbein, Nicolas. L'évolution Religieuse de Tolstoï. Paris: Cinq Continents, 1960.

13. Alston, Charlotte. Tolstoy and His Disciples: The History of a Radical International Movement. London: I. B. Tauris, 2014.

14. Avrich, Paul. "Russian anarchists and the civil war." Russian Review 27 (1968): 296-306. [CrossRef]

15. Brock, Peter. "Tolstoyism and the Hungarian peasant." Slavonic and Eastern European Review 58 (1980): 345-69.

16. Edgerton, William, ed. Memoirs of Peasant Tolstoyans in Soviet Russia. Bloomington: Indiana University Press, 1993.

17. Fueloep-Miller, Rene. "Tolstoy the apostolic crusader." Russian Review 19 (1960): 99-121. [CrossRef]

18. Holman, M. J. D. K. "The Purleigh colony: Tolstoyan togetherness in the late 1890s." In New Essays on Tolstoy. Edited by Malcolm Jones. Cambridge: Cambridge University Press, 1978, pp. 194-222.

19. Atack, Iain. Nonviolence in Political Theory. Edinburgh: Edinburgh University Press, 2012.

20. Christoyannopoulos, Alexandre. "Leo Tolstoy on the state: A detailed picture of Tolstoy's denunciation of state violence and deception." Anarchist Studies 16 (2008): 20-47.

21. Christoyannopoulos, Alexandre. Tolstoy's Political Thought. London: Routledge, forthcoming.

22. Hopton, Terry. "Tolstoy, God and anarchism." Anarchist Studies 8 (2000): 27-52.

23. McKeogh, Colm. Tolstoy's Pacifism. Amherst: Cambria, 2009.

24. Woodcock, George. "The prophet." In Anarchism: A History of Libertarian Ideas and Movements. Harmondsworth: Penguin, 1975.

25. Tolstoy, Leo. "A confession." In A Confession and Other Religious Writings. London: Penguin, 1987, pp. 17-80.

26. Tolstoy, Leo. "Some words about War and Peace." In War and Peace. Ware: Wordsworth, 1993, pp. 959-64.

27. Barran, Thomas. "Rousseau's political vision and Tolstoy's What is Art?" Tolstoy Studies Journal 5 (1992): $1-13$.

28. McLean, Hugh. “Rousseau's God and Tolstoy's God.” In In Quest of Tolstoy. Boston: Academic Studies Press, 2008, pp. 143-58.

29. Paperno, Irina. "Leo Tolstoy's correspondence with Nikolai Strakhov: The dialogue on faith." In Anniversary Essays on Tolstoy. Edited by Donna Tussing Orwin. Cambridge: Cambridge University Press, 2010, pp. 96-119. 
30. Christian, R. F. Tolstoy's Diaries. New York: Scribner, 1985, vol. 1.

31. Tolstoy, Leo. "The Gospel in brief." In A Confession and the Gospel in Brief. London: Oxford University Press, 1933, vol. 11, pp. 113-302.

32. Tolstoy, Leo. "What is religion, and wherein lies its essence? " In On Life and Essays on Religion. London: Oxford University Press, 1934, vol. 12, pp. 226-81.

33. Christoyannopoulos, Alexandre. "The golden rule on the green stick: Leo Tolstoy's international thought for a 'postsecular' age." In Towards a Postsecular International Politics: New Forms of Community, Identity, and Power. Edited by Luca Mavelli and Fabio Petito. London: Palgrave Macmillan, 2014, pp. 81-102.

34. Orwin, Donna Tussing. "Introduction: Tolstoy as artist and public figure." In The Cambridge Companion to Tolstoy. Edited by Donna Tussing Orwin. Cambridge: Cambridge University Press, 2002, pp. 49-62.

35. Christoyannopoulos, Alexandre. Christian Anarchism: A Political Commentary on the Gospel. Exeter: Imprint Academic, 2010.

36. Scanlan, James P. “Tolstoy among the philosophers: His book On Life and its critical reception." Tolstoy Studies Journal 18 (2006): 52-69.

37. Tolstoy, Leo. “On life." In On Life and Essays on Religion. London: Oxford University Press, 1934, vol. 12, pp. 1-167.

38. Maude, Aylmer. The Life of Tolstóy: Later Years. London: Oxford University Press, 1930, vol. 2.

39. Townsend, James. "The theology of Leo Tolstoy." Journal of the Grace Evangelical Society, 1998. Available online: http:/ / faithalone.org/journal/1998i/Townsend.html (accessed on 18 February 2016).

40. Wilson, A. N. Tolstoy: A Biography. New York: Norton, 1988.

41. Tolstoï, Lyof N. "My confession." In My Confession and the Spirit of Christ's Teaching. London: Walter Scott, 1887, pp. 1-149.

42. Tolstoy, Leo. "My confession." In The Complete Works of Count Tolstoy: My Confession and Critique of Dogmatic Theology. Edited by Leo Wiener. Boston: Colonial, 1904, vol. 13, pp. 3-90.

43. Tolstoy, Leo. "The teaching of Jesus." In On Life and Essays on Religion. London: Oxford University Press, 1934, vol. 12, pp. 346-409.

44. Tolstoy, Leo. "Introduction to an examination of the gospels." In A Confession and the Gospel in Brief. London: Oxford University Press, 1933, vol. 11, pp. 95-109.

45. Tolstoy, Leo. "Reason and religion: A letter to an inquirer." In On Life and Essays on Religion. London: Oxford University Press, 1934, vol. 12, pp. 199-204.

46. Tolstoy, Leo. What I Believe: My Religion. London: C. W. Daniel, 1902.

47. Maude, Aylmer. "Editor's note." In Recollections and Essays. London: Oxford University Press, 1937, vol. 21, pp. xi-xxxv.

48. Tolstoy, Leo. "Religion and morality." In On Life and Essays on Religion. London: Oxford University Press, 1934, vol. 12, pp. 168-98.

49. Orwin, Donna Tussing. "Courage in Tolstoy." In The Cambridge Companion to Tolstoy. Edited by Donna Tussing Orwin. Cambridge: Cambridge University Press, 2002, pp. 222-36.

50. Maurin, Peter. Easy Essays. Washington: Rose Hill, 2003.

51. Tolstoy, Leo. "The law of love and the law of violence." In A Confession and Other Religious Writings. London: Penguin, 1987, pp. 151-230.

52. Tolstoy, Leo. "The kingdom of God is within you: Christianity not as a mystical doctrine but as new understanding of life." In The Kingdom of God and Peace Essays. New Delhi: Rupa, 2001, pp. 1-421.

53. Schönle, Andreas. "Sublime vision and self-derision: The aesthetics of death in Tolstoy." In Anniversary Essays on Tolstoy. Edited by Donna Tussing Orwin. Cambridge: Cambridge University Press, 2010, pp. 33-51.

54. Knapp, Liza. "The development of style and theme in Tolstoy." In The Cambridge Companion to Tolstoy. Edited by Donna Tussing Orwin. Cambridge: Cambridge University Press, 2002, pp. 161-75.

55. Edmonds, Rosemary. “Introduction." In Resurrection. London: Penguin, 1966, pp. 5-16.

56. Tolstoy, Leo. "A reply to the synod's edict of excommunication, and to letters received by me concerning it." In On Life and Essays on Religion. London: Oxford University Press, 1934, vol. 12, pp. 214-25.

57. Tolstoy, Leo. "An appeal to the clergy." In On Life and Essays on Religion. London: Oxford University Press, 1934, vol. 12, pp. 282-308.

58. Tolstoy, Leo. "Church and state." In On Life and Essays on Religion. London: Oxford University Press, 1934, vol. 12, pp. 331-45. 
59. Tolstoy, Leo. "Letter to a non-commissioned officer." In Tolstoy's Writings on Civil Disobedience and Non-Violence. New York: Bergman, 1967, pp. 120-26.

60. Tolstoy, Leo. "How to read the Gospels and what is essential in them." In On Life and Essays on Religion. London: Oxford University Press, 1934, vol. 12, pp. 205-8.

61. Tolstoy, Leo. "The restoration of hell." In On Life and Essays on Religion. London: Oxford University Press, 1934, vol. 12, pp. 309-30.

62. Berdyaev, Nicolas. "The voice of conscience from another world: An introduction." In Essays From Tula. London: Sheppard, 1948, pp. 9-18.

63. Chesterton, G. K. “Tolstoy.” In Leo Tolstoy. Edited by G. K. Chesterton and G. H. Perris. London: Copp Clark Company, 1910, pp. 1-6.

64. Greenwood, E. B. Tolstoy: The Comprehensive Vision. London: Methuen, 1975.

65. Lyttelton, Edith. "Introduction to a confession and what I believe." In A Confession and the Gospel in Brief. London: Oxford University Press, 1933, vol. 11, pp. vii-xiv.

66. Matual, David. "The gospel according to Tolstoy and the gospel according to Proudhon." Harvard Theological Review 75 (1982): 117-28. [CrossRef]

67. Slonim, Marc. "Four western writers on Tolstoy." Russian Review 19 (1960): 187-204. [CrossRef]

68. Adams, Maurice. “The ethics of Tolstoy and Nietzsche." International Journal of Ethics 11 (1900): 82-105. [CrossRef]

69. Khudiev, Sergey. "The Trouble with Tolstoy." Available online: http://www.pravmir.com/the-trouble-withtolstoy/ (accessed on 18 February 2016).

70. Kolstø, Pål. "The demonized double: The image of Lev Tolstoi in Russian Orthodox polemics." Slavic Review 65 (2006): 304-24. [CrossRef]

71. Murray, Gilbert. "Introduction." In The Kingdom of God and Peace Essays. London: Oxford University Press, 1935, pp. vii-xvii.

72. Gustafson, Richard F. Leo Tolstoy: Resident and Stranger: A Study in Fiction and Theology. Princeton: Princeton University Press, 1986.

73. Tolstoy, Leo. "The Kingdom of God is within You: Christianity not as a Mystic Religion but as a New Theory of Life." Available online: http://www.nonresistance.org/docs_pdf/Tolstoy/The_Kingdom_Of_God_Is_ Within_You.pdf (accessed on 17 September 2010).

74. Yoder, John Howard. Christian Attitudes to War, Peace, and Revolution. Grand Rapids: Brazos, 2009.

75. Mavelli, Luca, and Fabio Petito, eds. Towards a Postsecular International Politics: New Forms of Community, Identity, and Power. London: Palgrave Macmillan, 2014.

76. Camilleri, Joseph A. "Postsecularist discourse in an 'age of transition'." Review of International Studies 38 (2012): 1019-39. [CrossRef]

77. Dallmayr, Fred. "Post-secularity and (global) politics: A need for radical redefinition." Review of International Studies 38 (2012): 963-73. [CrossRef]

78. Berger, Peter L., ed. The Desecularization of the World: Resurgent Religion and World Politics. Washington: W. B. Eerdmans, 1999.

79. Casanova, José. Public Religions in the Modern World. Chicago: University of Chicago Press, 1994.

80. Fox, Jonathan. A World Survey of Religion and the State. Cambridge: Cambridge University Press, 2008.

81. Fox, Jonathan. An Introduction to Religion and Politics: Theory and Practice. Oxon: Routledge, 2013.

82. Haynes, Jeffrey. An Introduction to International Relations and Religion. Harrow: Pearson, 2007.

83. Mavelli, Luca, and Fabio Petito. "The postsecular in international relations: An overview." Review of International Studies 38 (2012): 931-42. [CrossRef]

84. Tolstoy, Leo. Resurrection. London: Penguin, 1966.

85. Tolstoy, Leo. What is Art? New York: Funk \& Wagnalls Company, 1904.

86. Brooks, Jeffrey. When Russia Learned to Read: Literacy and Popular Literature, 1861-1917. Evanston: Norhwestern University Press, 2003.

87. McReynolds, Louise. The News under Russia's Old Regime: The Development of a Mass-Circulation Press. Princeton: Princeton University Press, 2014.

88. Von Gelden, James, and Louise McReynolds, eds. Entertaining Tsarist Russia: Tales, Songs, Plays, Movies, Jokes, ads, and Images from Russian Urban Life, 1779-1917. Bloomington: Indiana University Press, 1998. 
89. Aldridge, Alan E. Religion in the Contemporary World: A Sociological Introduction, 3rd ed. Cambridge: Polity, 2013.

90. Turner, Bryan S. Religion and Social Theory, 2nd ed. London: Sage, 1991.

91. Christoyannopoulos, Alexandre, and Joseph Milne. "Love, justice, and social eschatology." The Heythrop Journal 48 (2007): 972-91. [CrossRef]

92. Niebuhr, H. Richard. The Social Sources of Denominationalism. New York: Henry Holt, 1929.

93. Weber, Max. The Sociology of Religion. Boston: Beacon Press, 1963.

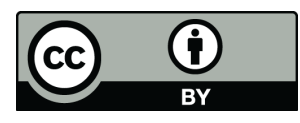

(C) 2016 by the author; licensee MDPI, Basel, Switzerland. This article is an open access article distributed under the terms and conditions of the Creative Commons Attribution (CC-BY) license (http:/ / creativecommons.org/licenses/by/4.0/). 